\title{
Is vaccination against hepatitis $B$ a reality among Primary Health Care workers?
}

\author{
Fernanda Marques da Costa $^{1}$ \\ Andréa Maria Eleutério de Barros Lima Martins² \\ Pedro Eleutério dos Santos Neto ${ }^{3}$ \\ Duran Nunes de Pinho Veloso 4 \\ Vilma Soares Magalhães ${ }^{5}$ \\ Raquel Conceição Ferreira ${ }^{6}$
}

Objective: To verify the prevalence and factors associated with vaccination against hepatitis $B$ among Primary Health Care workers in Montes Claros/MG. Method: A cross-sectional, analytic study was undertaken. Data were collected through a form, which contained sociodemographic, occupational, general health and behavioral variables. Associations were investigated through bivariate analysis and Poisson's multivariate regression, using SPSS 17.0. Results: 95.5\% answered the question about vaccination; $47.5 \%$ did not complete the vaccination scheme. The prevalence of vaccinated professionals was lower among older workers, who were hired, did not participate in occupational health updates and consumed alcohol. Prevalence levels were higher among professionals with more years of education and who reported contact with piercing and cutting instruments. Conclusions: Professional education, knowledge and perception of infection risks are important determinants of the vaccination scheme. Instability at work may lead to negligence and negligent behaviors may repeat themselves. The characterization of professionals who did not get vaccinated will direct educative actions in occupational health.

Descriptors: Hepatitis B; Vaccination; Occupational Health; Primary Health Care.

\footnotetext{
${ }^{1}$ Doctoral student and Professor, Universidade Estadual de Montes Claros, Montes Claros, MG, Brazil. Professor, Faculdades Integradas Pitágoras, Montes Claros, MG, Brazil. Professor, Faculdade de Saúde Ibituruna, Ibituruna, MG, Brazil.

2 PhD, Professor, Departamento de Odontologia, Universidade Estadual de Montes Claros, Montes Claros, MG, Brazil. Professor, Faculdades Unidas do Norte de Minas, Montes Claros, MG, Brazil.

${ }^{3}$ Doctoral student and Professor, Universidade Estadual de Montes Claros, Montes Claros, MG, Brazil. Professor Titular, Faculdades Unidas do Norte de Minas, Montes Claros, MG, Brazil.

${ }^{4}$ Undergraduate student in Dentistry, Universidade Estadual de Montes Claros, Montes Claros, MG, Brazil.

${ }^{5}$ Undergraduate student in Medicine, Universidade Estadual de Montes Claros, Montes Claros, MG, Brazil.

${ }^{6}$ PhD, Adjunct Professor, Faculdade de Odontologia, Universidade Federal de Minas Gerais, Belo Horizonte, MG, Brazil.
} 


\section{Introduction}

Hepatitis B represents an important public health problem around the world and one of the main morbidity and mortality causes among human beings ${ }^{(1)}$. Among health workers, the prevalence of infection by the hepatitis B virus (HBV) can range between 4.8 and $11.1 \%$ and may be up to thrice as high as in the general population $^{(1)}$. Possible justification for this situation include the high risk of occupational exposure, reaching up to $40 \%$ for percutaneous exposure in case of source patients who are serologically reactive to $\mathrm{HBsAg}{ }^{(2)}$.

Vaccination is the most effective form of prevention against hepatitis $B$ and, in Brazil, three vaccination doses are recommended (0, 1 and 6 months) for newborns, adolescents up to 19 years of age and health workers who may be exposed to biological materials in their activities, including workers who are not directly active in patient care ${ }^{(2)}$. Vaccination is also recommended before professionals (or students, trainees) are admitted to health services. In addition, seroconversion should be checked between one and two months after the final dose $^{(2)}$.

Most studies on vaccination against hepatitis $B$ include health professionals in specific areas, like Dentistry $^{(3)}$ and Nursing(4), undergraduate health students $^{(5)}$ and professionals working in hospital institutions $^{(6)}$. Only two studies on vaccination against hepatitis B were identified among Primary Health Care (PHC) workers in Brazil(7-8) and, despite its acknowledged importance, many workers still neglect it, which nonvaccination prevalence rates ranging between $23.8 \%{ }^{(7)}$ and $35.39 \%{ }^{(8)}$.

In Brazil, the Family Health Strategy (FHS) is the health care model that proposed the organization of PHC. Human resources working in FHS are organized based on multiprofessional team work, minimally including a physician, a nurse, a Nursing assistant, between four and six community health agents, a dentist and an oral health assistant and/or technician. These professionals experience a complex and peculiar work process, with large and increasing responsibilities ${ }^{(9)}$. This process demands technical and interpersonal relationship skills from these professionals, besides a collective understanding of the health-disease process ${ }^{(9)}$.

This work process determines different occupational health risks that can lead to workers' physical and/or mental illness, including biological risks(10-12). Hence, adherence to vaccination against hepatitis B should be considered in the context of FHS workers' health- disease process, including the study of variables that can be associated with different health behaviors, such as sociodemographic, lifestyle, health condition and occupational variables. In earlier studies, the prevalence of vaccination against hepatitis $B$ among health workers was lower among workers with lower education levels, a precarious employment $\operatorname{contract}^{(8)}$ and who did not participate in health recycling programs ${ }^{(7)}$. Contact with biological material and piercing-cutting instruments and smoking were also associated factors ${ }^{(8)}$.

Research on the prevalence and factors associated with vaccination against hepatitis B among $\mathrm{PHC}$ workers, characterizing professionals who did not get vaccinated, can contribute to guide actions aimed at reducing the incidence of this severe condition. Ideally, these actions should be part of other occupational health initiatives aimed at risk prevention and control in work environments.

In this study, the prevalence and factors associated with vaccination against hepatitis $\mathrm{B}$ were investigated among PHC workers, simultaneously analyzing factors that are considered important in determining vaccination against hepatitis B and which have not been studied earlier.

\section{Method}

This analytic and cross-sectional study was undertaken between August and December 2010 and included all 797 PHC workers of all 59 FHS teams in Montes Claros/MG: physicians, nurses, dental surgeons, nursing technicians and assistants, oral health technicians and assistants and community health agents. Data were collected through an interview, following a form that had been pilot tested among workers not considered in the main research. In the data collection form, besides questions elaborated for the research, the following scales validated in Brazil were included: Effort-reward imbalance ${ }^{(13)}$, General Health Questionnaire (GHQ) ${ }^{(14)}$, Whoqol-bref(15) and the International Physical Activity Questionnaire (IPAQ) ${ }^{(16)}$.

The dependent variable was reported vaccination, assessed through the following question "Have you been vaccinated against hepatitis $B$ ? If yes, how many doses have you taken?", with the following alternative answers: yes, 3 doses; yes, 2 doses; yes, one dose; yes, I do not know how many doses; not vaccinated. Workers who had received three doses of the vaccine against hepatitis $B$ were considered as vaccinated, while those who took one, two, none or did not know how many were considered as not vaccinated. 
The independent variables were grouped as follows: sociodemographic, occupational, general health variables and health-related behaviors.

As regards sociodemographic aspects, gender, age, education in years of study, marital situation (with or without partners) and monthly income in minimum wages were assessed. The quantitative variables age and monthly income were dichotomized, considering the median as the cut-off point.

With respect to occupational variables, the following were evaluated: function in FHS [categorized in three levels: higher (physicians, dental surgeons and nurses), technical (oral health technicians and nursing technicians) and primary and secondary (community health agents)]; professional experience in months; work regimen (fixed or hired); presence of other job; participation in recycling programs in occupational health during the last two years; contact with piercing-cutting instrument and biological material in current practice; accident history involving piercing-cutting instruments, stress level at work and satisfaction with work (satisfied or dissatisfied). The quantitative variable "professional experience in months" was dichotomized, considering the median as the cut-off point.

Among occupational variables, stress levels at work were assessed with the help of the Effort-reward Imbalance scale, which consists of 23 questions ${ }^{(13)}$, covering two extrinsic (effort and reward) and one intrinsic component (excessive commitment). The index between effort and reward at work was obtained by dividing the sum of effort scores by the sum of reward scores, considering the correction factor (0.545455). Next, this variable was dichotomized as scores $\leq 1$ (effort smaller than reward) or $>1.01$ (effort bigger than reward) ${ }^{(17)}$. Excessive commitment was analyzed as a quantitative variable, which means that, the higher the score, the greater the commitment at work.

General health assessment included self-classified health, evaluated through the following question: "How do you classify your health?", with the following response options: excellent, good, regular, bad or very bad. Two other questions assessed the presence of systemic illness(es) diagnosed by a physician (yes/no) and use of medicines prescribed by a physician (yes, no). The presence of mild mental disorders was assessed with the help of the General Health Questionnaire-12 (GHQ$12)^{(14)}$, which contains 12 questions with a four-point Likert scale for response. To analyze this instrument, the scoring system 0011 was used, in which answers that indicated the absence or presence of alterations in the aspect evaluated in the question were scored as 0 and 1 , respectively, with a possible total score between 0 and 12 . The cut-off point 3/4 was adopted to define individuals without and with mild mental disorders, respectively(18). The WHOQOL-bref $f^{(15)}$ was used to assess the general quality of life and its physical, environmental, social and psychological domains, scored between 0 and 100 according to World Health Organization orientations ${ }^{(19)}$. Quality of life scores were analyzed as a quantitative variable.

Physical exercise, alcohol consumption (yes/no) and smoking (current smoker, former smoker or never smoked) were assessed as health-related behaviors. To evaluate physical exercise, the International Physical Activity Questionnaire (IPAQ)(16) was used, analyzed according to the orientations of the Study Center of the Physical Fitness Laboratory in São Caetano do Sul(20), classifying workers as very active, active, irregularly active and sedentary. This variable was later categorized as active (very active, active) and sedentary and irregularly active.

Statistical analyses were developed in SPSS $^{\circledR}$ version 17.0 for Windows. After descriptive analysis, the association between reported vaccination and the independent variables was investigated through bivariate analysis and Poisson's multivariate regression. Variables associated with reported vaccination in bivariate analysis and $\mathrm{p}<0.30$ were included in the multivariate analysis. Significance was set at 95\%. The final model was adjusted and those variables associated with $\mathrm{p}<0.05$ were maintained.

The research project Factors associated with immunization against hepatitis $B$ among Primary Health Care workers, which gave rise to this study, received approval from the Institutional Review Board at Funorte (CEP/SOEBRAS: 0208/08).

\section{Results}

At the time of data collection, 797 workers were active in FHS in Montes Claros. The response rate obtained was $95.6 \%(n=762)$, with 761 (95.5\%) workers answering the question about vaccination against hepatitis B. Approximately half (52.5\%) reported having taken three doses of the vaccine against hepatitis $B$. The $4.4 \%$ loss referred to workers who were not met after three attempts.

The following factors were associated with reported vaccination against hepatitis $B$ in bivariate analysis $(p<0.05)$ : education in years, monthly income, function 
in FHS; professional experience; having another job; participation in occupational health recycling programs in the last two years; contact with piercing-cutting materials in current practice, contact with biological material in current practice, accident history involving piercing-cutting instruments, general quality of life and in the physical, psychological, social and environmental domains, smoking and physical exercise (Tables 1, 2 and 3).

Table 1 - Bivariate analysis result between reported vaccination against hepatitis B and sociodemographic variables among Primary Health Care workers, Montes Claros, MG, Brazil, $2010(n=761)$

\begin{tabular}{|c|c|c|c|c|c|c|c|}
\hline & \multicolumn{7}{|c|}{ Vaccination against hepatitis $B$} \\
\hline & \multicolumn{2}{|c|}{ Yes } & \multicolumn{2}{|c|}{ No } & \multirow{2}{*}{ PR } & \multirow{2}{*}{$95 \% \mathrm{Cl}$} & \multirow{2}{*}{$p$-value } \\
\hline & $\mathbf{N}$ & $\%$ & $\mathbf{N}$ & $\%$ & & & \\
\hline \multicolumn{8}{|l|}{ Gender } \\
\hline Male & 74 & 48.4 & 79 & 51.6 & 1.00 & & \\
\hline Female & 326 & 53.6 & 282 & 46.4 & 1.11 & $0.92-1.33$ & 0.26 \\
\hline \multicolumn{8}{|l|}{ Age range } \\
\hline$\leq 30$ years & 222 & 55.4 & 179 & 44.6 & 1.00 & & \\
\hline$>31$ years & 178 & 49.4 & 182 & 50.6 & 0.89 & $0.78-1.02$ & 0.11 \\
\hline Education (years of study) & & & & & 1.07 & $1.06-1.09$ & 0.00 \\
\hline \multicolumn{8}{|l|}{ Marital Situation } \\
\hline Partner & 196 & 50.6 & 191 & 49.4 & 1.00 & & \\
\hline No partner & 204 & 55.0 & 167 & 45.0 & 1.09 & $0.95-1.24$ & 0.23 \\
\hline \multicolumn{8}{|l|}{ Monthly income } \\
\hline$\geq 1.17$ Minimum Wages & 214 & 61.1 & 136 & 38.9 & 1.00 & & \\
\hline Up to 1.16 Minimum Wages & 167 & 44.1 & 212 & 55.9 & 0.72 & $0.63-0.83$ & $<0.001$ \\
\hline
\end{tabular}

Table 2 - Bivariate analysis result between reported vaccination against hepatitis $B$ and occupational variables among Primary Health Care workers, Montes Claros, MG, Brazil, $2010(n=761)$

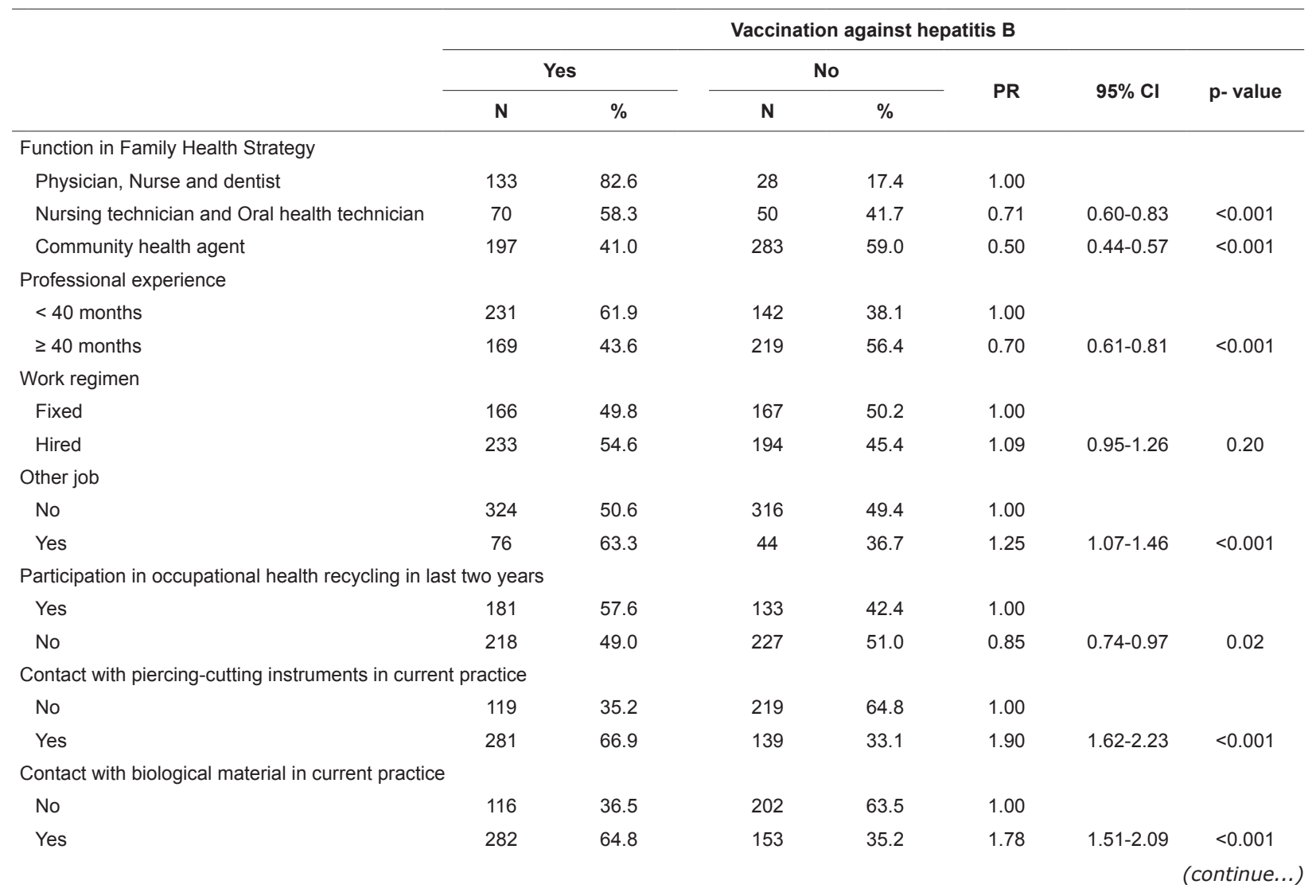


Table 2 - (continuation)

\begin{tabular}{|c|c|c|c|c|c|c|c|}
\hline & \multicolumn{7}{|c|}{ Vaccination against hepatitis $B$} \\
\hline & \multicolumn{2}{|c|}{ Yes } & \multicolumn{2}{|c|}{ No } & \multirow{2}{*}{ PR } & \multirow{2}{*}{$95 \% \mathrm{Cl}$} & \multirow{2}{*}{ p-value } \\
\hline & $\mathbf{N}$ & $\%$ & $\mathbf{N}$ & $\%$ & & & \\
\hline \multicolumn{8}{|l|}{ Occupational accident history } \\
\hline No & 335 & 50.2 & 332 & 49.8 & 1.00 & & \\
\hline Yes & 65 & 69.1 & 29 & 30.9 & 1.38 & $1.18-1.61$ & $<0.001$ \\
\hline \multicolumn{8}{|l|}{ Effort - Reward Index at work } \\
\hline$\leq 1.00$ (Effort < Reward) & 128 & 54.0 & 109 & 46.0 & 1.00 & & \\
\hline$>1.01$ (Effort > Reward) & 249 & 53.7 & 215 & 46.3 & 0.99 & $0.86-1.15$ & 0.93 \\
\hline Excessive commitment at work & & & & & 1.02 & $0.99-1.05$ & 0.18 \\
\hline \multicolumn{8}{|l|}{ Satisfaction with work } \\
\hline Satisfied & 321 & 53.1 & 284 & 46.9 & 1.00 & & \\
\hline Dissatisfied & 78 & 50.3 & 77 & 49.7 & 0.95 & $0.80-1.13$ & 0.55 \\
\hline
\end{tabular}

Table 3 - Bivariate analysis result between reported vaccination against hepatitis $B$ and general health variables and health-related behaviors among Primary Health Care workers, Montes Claros, MG, Brazil, $2010(n=761)$

\begin{tabular}{|c|c|c|c|c|c|c|c|}
\hline & \multicolumn{7}{|c|}{ Vaccination against hepatitis $B$} \\
\hline & \multicolumn{2}{|c|}{ Yes } & \multicolumn{2}{|c|}{ No } & \multirow{2}{*}{ PR } & \multirow{2}{*}{$95 \% \mathrm{Cl}$} & \multirow{2}{*}{ p-value } \\
\hline & $\mathbf{N}$ & $\%$ & $\mathbf{N}$ & $\%$ & & & \\
\hline \multicolumn{8}{|l|}{ Self-classified health } \\
\hline Excellent, good and regular & 374 & 53.7 & 323 & 46.3 & 1.00 & & \\
\hline Bad and very bad & 24 & 40.0 & 36 & 60.0 & 0.74 & $0.54-1.02$ & 0.07 \\
\hline \multicolumn{8}{|l|}{ Presence of mental disorder } \\
\hline No & 305 & 53.5 & 265 & 46.5 & 1.00 & & \\
\hline Yes & 82 & 49.7 & 83 & 50.3 & 0.93 & $0.78-1.10$ & 0.39 \\
\hline \multicolumn{8}{|l|}{ Quality of life } \\
\hline Physical Domain & & & & & 1.01 & $1.00-1.01$ & 0.03 \\
\hline Psychological Domain & & & & & 1.01 & $1.00-1.02$ & $<0.001$ \\
\hline Social Domain & & & & & 1.01 & $1.00-1.01$ & $<0.001$ \\
\hline Environmental Domain & & & & & 1.02 & $1.01-1.02$ & $<0.001$ \\
\hline General quality of life & & & & & 1.01 & $1.00-1.01$ & $<0.001$ \\
\hline \multicolumn{8}{|l|}{ Alcohol consumption } \\
\hline No & 234 & 54.3 & 197 & 45.7 & 1.00 & & \\
\hline Yes & 166 & 50.3 & 164 & 49.7 & 0.93 & $0.81-1.06$ & 0.28 \\
\hline \multicolumn{8}{|l|}{ Smoking } \\
\hline Non smoker & 382 & 53.8 & 328 & 46.2 & 1.00 & & \\
\hline Smoker or former smoker & 18 & 35.3 & 33 & 64.7 & 0.66 & $0.45-0.96$ & 0.03 \\
\hline \multicolumn{8}{|l|}{ Physical exercise } \\
\hline Active & 299 & 50.3 & 296 & 49.7 & 1.00 & & \\
\hline Sedentary/lrregularly active & 101 & 60.8 & 65 & 39.2 & 1.21 & $1.05-1.40$ & 0.01 \\
\hline \multicolumn{8}{|l|}{ Presence of systemic disease(s) } \\
\hline No & 270 & 51.6 & 253 & 48.4 & 1.00 & & \\
\hline Yes & 124 & 55.4 & 100 & 44.6 & 1.07 & $0.93-1.24$ & 0.34 \\
\hline \multicolumn{8}{|l|}{ Medication use } \\
\hline No & 295 & 52.3 & 269 & 47.7 & 1.00 & & \\
\hline Yes & 98 & 53.3 & 86 & 46.7 & 1.02 & $0.87-1.19$ & 0.82 \\
\hline
\end{tabular}

In multivariate analysis, a lower prevalence of vaccinated workers was found among older, hired professionals, who had not participated in occupational health recycling program in the last two years and who reported alcohol consumption. The prevalence of vaccination was higher among workers with more years of education and who reported contact with piercingcutting instruments in current practice (Table 4). 
Table 4 - Final model of factors associated with reported vaccination against hepatitis B among Primary Health Care workers. Montes Claros, MG, Brazil, 2010

\begin{tabular}{|c|c|c|c|}
\hline Independent Variables & PR & $95 \% \mathrm{Cl}$ & p-value \\
\hline \multicolumn{4}{|l|}{ Age range } \\
\hline$\leq 30$ years & 1 & & \\
\hline$>31$ years & 0.84 & $0.74-0.95$ & 0.007 \\
\hline Education in years of study & 1,06 & $1.04-1.08$ & $<0.001$ \\
\hline \multicolumn{4}{|l|}{ Work regimen } \\
\hline Fixed & 1 & & \\
\hline Hired & 0.84 & $0.72-0.97$ & 0.017 \\
\hline \multicolumn{4}{|c|}{ Recycling in occupational health in the last two years } \\
\hline Yes & 1 & & \\
\hline No & 0.80 & $0.70-0.91$ & 0.001 \\
\hline \multicolumn{4}{|c|}{ Contact with piercing-cutting instruments in current practice } \\
\hline No & 1 & & \\
\hline Yes & 1.70 & $1.43-2.02$ & $<0.001$ \\
\hline \multicolumn{4}{|l|}{ Alcohol consumption } \\
\hline No & 1 & & \\
\hline Yes & 0.84 & $0.74-0.96$ & 0.009 \\
\hline
\end{tabular}

\section{Discussion}

Prevalence rates of reported vaccination were low among PHC workers in Montes Claros/MG. This fact is concerning, as the Ministry of Health recommends vaccination against hepatitis $B$ for $100 \%$ of health workers $^{(2)}$. In Brazil, the prevalence of vaccination among $\mathrm{PHC}$ workers in Florianópolis ${ }^{(8)}$ and Mato Grosso do Sul(7) corresponded to $64.61 \%$ and $76.2 \%$, respectively, higher than the $52.5 \%$ observed in this study. Health workers need to follow this recommendation, as the vaccine has been proven safe $^{(3)}$ and the most effective way to prevent infection by $\mathrm{HBV}^{(7-8)}$. Besides vaccination, adherence to standard precaution measures and caution by workers are fundamental to avoid HBV transmission in health services, not only with a view to their own, but also their patients and relatives' protection(5).

Those study results evidenced the importance of professional education and knowledge in determining vaccination against hepatitis $B$, as its prevalence was higher among younger professionals who had participated in occupational health recycling programs in the last two years. These associations can reflect differences in these professionals' knowledge on occupational protection measures, including vaccination. Younger workers possibly had further access to information on infection control as a result of the aids epidemic. Another benefit for this group was that the Ministry of Health made hepatitis B vaccination available as from $1995^{(3)}$.

Vaccination prevalence rates were higher among workers with more years of education, possibly due to the greater perception of occupational risks ${ }^{(7,21)}$ and further knowledge on occupation health ${ }^{(4,8)}$ among professionals with higher education levels. In addition, professionals with a higher education degree may have been vaccinated during their undergraduate program ${ }^{(21)}$. Similarly, in a cross-sectional study in a hospital context, lower vaccination prevalence rates were observed among nursing auxiliaries, related to their low education level and higher vaccination prevalence in occupations with higher education levels(22). Related to this finding, among dental surgeons in Montes Claros, higher prevalence of reported vaccination was observed among professionals who participated in occupational health training, demonstrating that, even among highereducation professionals, further occupational health knowledge is a factor that favors vaccination against hepatitis $\mathrm{B}^{(21)}$.

As previously observed(7), because they are more exposed to occupational accident risks, workers who have contact with piercing-cutting instruments in their current practice reveal higher prevalence rates of reported vaccination. These professionals possibly know that cases of percutaneous exposure are associated with greater risk of pathogen transmission and responsible for higher prevalence rates of occupational accidents ${ }^{(2)}$, making them adopt self-care measures more frequently. It should be highlighted that workers who have contact with piercing-cutting instruments face greater accident risks and may have been more emphatically oriented to get vaccinated. The variable "accident history involving piercing-cutting instruments" was not significantly 
associated with reported vaccination and the prevalence of workers who got vaccinated was similar among workers who were victims of accidents or not. Whether the accident made the professionals seek vaccination is a matter of discussion, increasing the prevalence of vaccinated workers among accident victims. Nevertheless, even among victims, approximately $1 / 3$ did not get vaccinated. In the present study, the measures professionals adopted after an accident involving biological material were not assessed, but should be considered in future research.

In this study, vaccination prevalence rates were lower among workers who consumed alcohol, which may mean a repetition of negligent behavior towards their own health, including non-vaccination. Alcohol consumption does not necessarily mean negligence towards health though and, depending on the type of beverage and usage characteristics, it can be considered a self-care measure; to give an example, moderate red wine consumption as an auxiliary prevention measure against diabetes and cardiovascular diseases(23). The abuse of liquor and distilled beverages, on the other hand, can be considered a marker of negligence towards one's own health. In this study, the variable "alcohol consumption" was assessed dichotomously, without the possibility to discuss variations in vaccination prevalence regarding the type, quantity and frequency of alcohol consumption. Despite this limitation, the dichotomous variable was capable of identifying workers whose alcohol consumption behavior was associated with another health-related behavior: vaccination. As the sense of this association was inverse, the hypothesis of health negligence was raised. The consistency of this finding could not be verified, as this variable had not been previously investigated among PHC workers(7-8).

Considering vaccination as a preventive and selfcare measure, recommended for health professionals, its prevalence was studied in the broader health context, in the attempt to identify its association with positive and negative factors that could interfere in health behaviors. Dissatisfaction and stress at work, mental illness, low quality of life and high prevalence of sedentariness ${ }^{(24)}$ have been reported among health professionals, who recognize many risks of illness in their own work process ${ }^{(12)}$. Therefore, variables like stress at work, quality of life, physical exercise, mental health, systemic illnesses, which had not been tested in earlier studies, were included in the analysis, in the belief that unfavorable situations in this respect could interfere in health behaviors and self-care measures, including vaccination against hepatitis $B$. This hypothesis was not confirmed. The work regimen variable, however, who assessed the worker's situation in terms of job stability, was significantly associated with reported vaccination.

The prevalence of reported vaccination among hired workers was lower than among fixed workers. In an earlier study, workers with a precarious job contract revealed lower vaccination $\operatorname{rates}^{(8)}$. Precarious employment may be associated with deteriorated occupational health in terms of accidents, disease risk, dangerous exposures and knowledge on occupational safety and health. Absence of professional benefits, increasing requirements with regard to productivity and new skills, lack of stability at work, low professional acknowledgement and high turnover levels can discourage workers who, in general, may be less concerned with their health ${ }^{(22)}$ or present less wellbeing at work $^{(11,25)}$.

This study indicated the need to train PHC workers in Montes Claros as regards biosafety, health and occupational safety, including clarifications about the benefits of vaccination against hepatitis $B$. Updates need to be part of a long-term continuing education plan, followed by evaluation mechanisms. Human resource guidelines and proposals for the Unified Health System, in accordance with Decree 1.125 issued in 2005(3), establish support for training with emphasis on biosafety for workers exposed to risk situations. In addition, the decree establishes the reduction of occupational accidents and illnesses through prevention and health surveillance actions, including comprehensive health care. In the same sense, workers can be attended in State and Regional Occupational Health Referral Centers (Cerest), which are medium and high-complexity care institutions capable of diagnosing health problems related to work, including hepatitis $B$.

Also, vaccination campaigns need to be highlighted as fundamental actions as, besides reducing the prevalence of hepatitis $B$, they may positively affect workers' satisfaction, who may feel valued at work and, therefore, more motivated. In Montes Claros, a favorable result in the prevalence of reported vaccination against hepatitis B among dental surgeons in 2002, the highest rate described in Brazil at that time, 74.9\%, may have been due to a vaccination campaign for health professionals and students, held before the study ${ }^{(14)}$. The result also evidenced that negligent behaviors towards health seem to be recurrent. This points towards joint occupational health promotion actions, adding alcoholism prevention for example. 
The present study results demonstrate internal validity, considering the high response rate, but may be overestimated as they consider workers' reports, who may choose answers that are considered correct, even if they do not represent the reality of their practice. To minimize this bias, the interviewers were trained, informing participants about the confidentiality of any data provided.

\section{Conclusion}

The prevalence rate of vaccination against hepatitis $B$ is low among PHC workers in Montes Claros. The results reveal the importance of professional education, knowledge and infection risk in the determination of hepatitis B vaccination. They also suggest that instability at work can lead to negligence through nonvaccination and that negligent health-related behaviors are repeated.

\section{References}

1. Ministério da Saúde (BR). Secretaria de políticas de saúde coordenação nacional de DST, Aids e Hepatites Virais. ABCDE Diagnóstico para Hepatites Virais. Brasília; 2009.

2. Ministério da Saúde (BR). Exposição a materiais biológicos. Brasília: MS; 2006.

3. Resende VLS, Abreu MHG, Paiva SM, Teixeira R, Pordeus IA. Concerns regarding hepatitis $B$ vaccination and post-vaccination test among Brazilian dentists. Virol J. [periódico na Internet]. 2010. [acesso 26 jun 2011];7(1):7-154. Disponível em: http://www. virologyj.com/content/7/1/154

4. Pinheiro J, Zeitoune RCG. Hepatite B: conhecimento e medidas de biossegurança e a saúde do trabalhador de enfermagem. Esc Anna Nery. 2008;12(2):258-64.

5. Gir E, Netto JC, Malaguti SE, Canini SRMS, Hayashida M, Machado AA. Accidents with biological material and immunization against hepatitis $B$ among students from the health area. Rev. Latino-Am. Enfermagem. [periódico na Internet]. 2008. [acesso 16 jul 2011];(3):401-6. Disponível em: http://www.scielo.br/ scielo.php?script=sci_arttext\&pid=S0104-

6. Canini SRMS, Gir E, Machado AA. Accidents with potentially hazardous biological material among workers in hospital supporting services. Rev. Latino-Am. Enfermagem. 2005;13(4):496-500. Inglês, Português, Espanhol.

7. Sanches GBS, Honer MR, Pontes ER, Aguiar JI, Ivo ML. Caracterização soroepidemiológica da infecção do vírus da hepatite $B$ em profissionais de saúde da atenção básica no Estado de Mato Grosso do Sul, Brasil. Rev Panam Infectol. 2008;10(2):17-5.

8. Garcia LP, Facchini LA. Vacinação contra hepatite B entre trabalhadores da atenção básica a saúde. Cad Saude Publica. 2008;24(5):1130-40.

9. Tomasi E, Facchini LA, Piccini RX, Thumé E, Silveira DS, Siqueira FV, et al. Perfil sócio-demográfico e epidemiológico dos trabalhadores da atenção básica à saúde nas regiões Sul e Nordeste do Brasil. Cad Saúde Pública. 2008;24(Sup 1):193-201.

10. Cardoso AC, Figueiredo RM. Biological risk in nursing care provided in family health units. Rev. Latino-Am. Enfermagem. [periódico na Internet]. 2010 June [acesso 13 jun 2011]; 18(3):368-72. Disponível em: http://www. scielo.br/scielo.php?script=sci_arttext\&pid=S0104$11692010000300011 \&$ Ing=en. http://dx.doi. org/10.1590/S0104-11692010000300011.

11. Shimizu HE, Carvalho Jr. DAC. O processo de trabalho na Estratégia Saúde da Família e suas repercussões no processo saúde-doença. Cien Saude Coletiva. 2012;17(9):2405-14.

12. Cezar-Vaz MR; Soares JFS, Figueiredo PP, Azambuja $E P$, Sant'Anna CF, Costa VZ. Risk perception in Family health work: study with workers in Southern Brazil. Rev. Latino-Am. Enfermagem. 2009;17(6):961-7.

13. Silva LS, Barreto SM. Adaptação transcultural para o português brasileiro da escala effort-reward imbalance: um estudo com trabalhadores de banco. Rev Panam Salud Publica. 2010;27(1):32-6.

14. Gouveia VV, Chaves SSS, Oliveira ICP. A utilização do QSG-12 na População Geral: Estudo de sua Validade de Construto. Psicologia: Teor Pesq. 2003;19(3):241-7. 15. Fleck MPA, Louzada S, Xavier M, Chachamovich E, Vieira G, Santos L, et al. Aplicação da versão em português do instrumento WHOQOL-bref. Rev Saude Pública. 2000;34(2):178-83.

16. Craig CL, Marshall AL, Sjöström M, Bauman AE, Booth $M L$, Ainsworth $B E$, et al. International Physical Activity Questionnaire: 12-Country Reliability and Validity. Med Sci Sports Exerc. 2003;35(1):1381-95.

17. Fogaça MC, Carvalho WB, Cítero VA, NogueiraMartins LA. Preliminary study about occupational stress of physicians and nurses in pediatric and neonatal intensive care units: the balance between effort and reward. Rev. Latino-Am. Enfermagem. [periódico na Internet]. 2010 Feb [acesso 13 jun 2012]; 18(1):67-72. Disponível em: http://www. scielo.br/scielo.php?script=sci_arttext\&pid=S010411692010000100011 \&lng=en. http://dx.doi. 
org/10.1590/S0104-11692010000100011.

18. Goldberg DP, Gater R, Sartorius N, Ustun TB, Piccinelli $M$, Gureje $O$, et al. The validity of two versions of the GHQ in the WHO study of mental illness in general health care. Psychol Med. 1997;27(01):191-6.

19. Harper P. Steps for checking and cleaning data and computing domain scores for the whoqol-bref. [acesso 14 nov 2010]. Disponível em: www.ufrgs.br/psiq/ whoqol86.html

20. Celafiscs- Centro de Estudos do Laboratório de Aptidão Física de São Caetano do Sul. Questionário Internacional de Atividade Física - versão curta. [acesso 14 nov 2010] Disponível em: www.celafiscs.com.br IPAQ.

21. Martins AMEBL, Barreto SM. Vacinação contra a hepatite B entre cirurgiões dentistas. Rev Saude Pública. 2003;37(3):333-8

22. Silva RJO, Athayde MJPM, Silva LGP, Braga EA, Giordano MV, Pedrosa ML. Vacinação anti-hepatite B em profissionais da saúde. DST J Bras Doenças Sex Transm 2003;15(1):51-5.

23. Chiva-Blanch G, Urpi-Sarda M, Ros E, ValderasMartinez P, Casas R, Arranz S, et al. Effects of red wine polyphenols and alcohol on glucose metabolism and the lipid profile: A randomized clinical trial. Clin Nutr. 2012;S0261-5614(12)00189-6. doi: 10.1016/j. clnu.2012.08.022. [Epub ahead of print]

24. Siqueira FCV, Nahas MV, Fachini LA, Piccini RX, Tomasi $E$, Thumé $E$, et al. Atividade física em profissionais de saúde do Sul e Nordeste do Brasil Cad Saude Pública. 2009;25(9):1917-28.

25. Alves PC, Neves VF, Coleta MFD, Oliveira ÁF. Evaluation of well-being at work among nursing professionals at a University Hospital. Rev. Latino-Am. Enfermagem. [periódico na Internet]. 2012 Aug [acesso 13 jun 2012];20(4):701-9. Disponível em:http://www. scielo.br/scielo.php?script=sci_arttext\&pid=S0104$11692012000400010 \&$ Ing $=$ en. 